\title{
MENTALITY AND THE PROBLEM OF IDENTITY IN THE CONTEXT OF MODERNITY
}

\author{
Skotna N. V.
}

\section{INTRODUCTION}

The relevance of the chosen topic is attributed to the fact that in modern conditions, along with the tendency of integration, there is another one disintegration, which is manifested in the country's ethnic, confessional and civilization crisis. The last few decades were characterized by the two differently directed processes: the process of globalization and the process of particularization, that is, separation, individualization. Unfortunately, "the world history shows that civilizational identity is not able to prevent conflicts originating from national, tribal or community identities, and its unifying role, as well as national identity, has often been punctuated by the disintegrating influence of class, social, ethnic, clan, denominational and other identities, although their mobilization value is now significantly diminished"1. Today, the destruction of major social institutions related to the process of social and self-identification of the individual leads to the loss of meaning in life, disorientation and de-identification of the members of society. In such a situation, the citizens of any country continue to question the very basics of the ontological authenticity of anything in the world, subconsciously realizing that they lack deep and reliable relationships and values. Not only the surrounding world ceased to be transparent and familiar to a man, but also a man to himself.

Therefore, it is important to understand the common and distinctive features of the Ukrainian society that lead to conflicts or their resolution.

Undoubtedly, the category of "mentality" opens the way to understanding the various aspects of spiritual life, the secrets of individual and collective consciousness, the peculiarities of the national spirit of the people, their character, habits and primal interests. The very concept of mentality, according to the researchers, shows that collective emotions and typical reactions of ethnos affect social relations no less than rational motives. Indeed, the peculiarities of worldview and consciousness play a prominent role in the history of any nation, state. That is, we are talking about the

${ }^{1}$ Кузьменко Н.І. Постмодерний університет і цивілізаційна ідентичність: ціннісний аспект / Н.І. Кузьменко, О.О. Демченко // Вісник НТУу “КПІ”. Філософія. Психологія Педагогіка. - 2014. - Вип. 3. - С. 12. 
presence in the mind of a human rod, which may under different external conditions change its face, but which remains uniform for the whole ethnic group and serves as an internal cultural integrator.

The concept of "mentality" reflects a special world of peoples' existence, their spiritual potential. As an effective methodological tool, this category, in which the mentality becomes a kind of community memory about its past, ancestral memory, system of people's perception and behavior, allows to determine the state of the community and its culture, to explore its current problems. Thus, national mentality always retains the potential to influence changes in the society. In certain circumstances, it is capable of acting either as an inertial force that impedes changes in the society or acts as a basis for accelerating and validating these processes.

\section{Mentality in the context of modern Ukrainian society}

Mentality permeates the life of an ethnic group being absorbed by people from their very childhood as the only possible way of world perception. Mentality is the very general "background" on which the individual and the social are superimposed. Firstly, mentality in a concentrated form expresses the specific nature of the culture of both individual and collective subject, secondly, it is formed under the influence of certain social and cultural conditions, and thirdly, it has a significant impact on the development of community and history. Also, the concept of "mentality" helps to distinguish a certain group (ethnicity, nation, people) from representatives of other cultures. Distinguishing between "us" and "them" is the main purpose of the concept of mentality, especially since "own" mentality acquires formalization only against the backdrop of "their" mentality, with carriers of which it may have far from simple relationships.

As R.A. Dodonov notes, "in modern humanitarian knowledge there is a stable interdisciplinary dependence in the study of ethnic mentality, which practically blurs the line between psychology, sociology, ethnology, semiotics, cultural studies, and historical science. A synergistic method that generalizes the results of these natural and humanitarian branches of knowledge and logically purifies them also contributes to a systematic look at ongoing processes."

The term "mentality" was introduced by R. Emerson (1856), and, as a concept, was later developed by M. Proust, who, noting its novelty, tried to describe the related phenomena. Lévy-Bruhl's research presents a distinction between two types of mentality - pre-logical and logical. The French historian

2 Додонов Р.А. Этническая ментальность: опыт социально-философского исследования: Монографія / Р. А. Додонов. - Запорожье: “Тандем-У”, 1998. - С. 35. 
J. Lefebvre introduced the idea of a "collective mentality" that reflected the psychology of the crowd, whose behavior, especially in times of crisis, could not be explained without taking into account its structure. The structures also appeared for Lefebvre as a kind of biologically determined constants. The Annales School (L. Febvre, M. Bloch) deprives the notion of mentality of the biologized interpretation. On the basis of A. Wallon and Ch. Blondel's works appeared the contours of historical or socio-historical psychology, elaborated further by Meyerson and other researchers. Mentality begins to be understood as a system that is constantly on the move and thus can be the object of history. It is a system of images, representations that, in different groups or countries, lie in the core of the people's perception of the world and of their place in this world and, consequently, determine their actions and behavior.

Taking into account the "classical" or "academic" approach in the study of the history of mentality, its representatives reconstructed mainly the worldview of the past epochs with a clear awareness of temporal distance and distant perception; whereas we focus our attention on understanding mentality of The Annales School - French "historians", L. Febvre M. Block, J. Duby and their followers (M. Kostomarov, S. Solovyov, M. Berdyaev and others). This approach regards the culture that supports sustainability of mentality as well as the possible sources of various transformations - the whole "life world" of people in its development. While the classical concept examines the horizontal section of history in its static, the representatives of the indicated direction try to cognize the basic principles of the phenomenon in the context of current events.

The Annals School used the term mentality (mentality) to identify the rational attitudes and "spiritual equipments" of various social groups, including ethnic groups, while emphasizing the study of the unconscious, mundane, and superpersonal aspects of individual consciousness. Any innovation, from the perspective of this school, is expressed in the process of a predetermined language system and cultural tradition that sets the boundaries for the subject. Culture and tradition, language, lifestyles and religiosity form the kind of matrix within which mentality is formed.

A. Gurevich described the three properties of mentality.in the collection "50/50. The Experience of the Dictionary of New Thinking", in which the French and Soviet scholars contrasted their understanding of important for socio-philosophical knowledge concepts. First, it is the vibrant and volatile with the striking stability of a constant magma of life mindsets, beliefs and

${ }^{3}$ Гуревич А.Я. Ментальность / М. Вовель, А. Гуревич, М. Рожанский // 50/50. Опыт словаря нового мышления. [Под общ. ред. Ю. Афанасьева и М. Ферро]. - М. : Прогресс Payot. 1998. - C. 454-463. 
patterns of behavior, emotions and moods based on the deep zones inherent in a given society and cultural tradition. Secondly, the mentality of a society is not monolithic: in reality, it is divided into a complex conglomerate of religious, national, nomenclature-bureaucratic, totalitarian, and other mentalities that are far from being fully conditioned by social reality (ideology, social institutions, etc.). Thirdly, when it comes to mentality, these are is not certain fully understood and more or less clearly formulated ideas and principles, but the specific meaning that people have in them. He then offers a generalized metaphor for mentality. It is, in principle, an inexhaustible picture of the world in the mind of a man: the "universe" of ideas about the individual and society, about freedom, equality, good and evil, about power and rulers, law and work, about family and sexual relations, about the course of history and the values of time, about death and soul, about friend-or-foe, violence and honor. It is this multidimensional picture inherited from previous generations and changing in the process of social practice, which programs human behavior.

According to R. Dodonov "The concept of mentality reflects a specific type of collective perception of the natural and social environment, and the content of this phenomenon should be sought not in the a priori structures of human consciousness, but in the external environment of ethnic communities, where the roots of the process of the genesis of mentality lie"4.

The Ukrainian mentality is defined by the peculiarities of the social and cultural situation that has historically formed in Ukraine. "For many centuries the present-day territory of Ukraine has been part of the ever-shifting internal borders: between linguistic and ethnic groups, states, religions, political and cultural systems, arenas of different economic structures. This made it a strongly-pronounced contact area with a very varied spectrum of sociocultural phenomena"5.

Also, there is a periodic accumulation of unrealized potential of several generations, who, due to objective circumstances, are living in one time, which they cannot call "their own". The post-Soviet mentality consists of three levels - Ukrainian (traditional), Soviet (modernist), and Ukrainian (postmodern).

The reference to the notion of mentality must confirm the fact that all these times exist simultaneously in Ukraine. The traditional mentality must be co-opted with the Soviet mentality and what we are beginning to see as the

4 Додонов Р.А. Этническая ментальность: опыт социально-философского исследования: Монографія / Р.А. Додонов. - Запорожье: “Тандем-У”, 1998. - С. 77.

${ }^{5}$ Яковенко Н. Паралельний світ. Дослідження з історії уявлень та ідей в Україні XVI XVII ст. / Н. Яковенко. - Київ : Критика, 2002. - С. 333. 
post-Soviet mentality. As a consequence - mass disorientation, loss of identification at all levels - individual, group, at the level of society as a whole. A significant consequence of the totalitarian era is also the superficial symbolic identification, a set of meanings that ensured the legitimacy of the system as a whole and integrated the Soviet Union as a whole. The peculiarity of such a mentality is the enslavement, simplification, restriction of the variety of inquiries about the quality of life or information interests, which are transformed into an awareness of the "victim" of history, the hostile forces that determine the mass perception of events. Hence - the stability of the functional role of "enemy", "stranger". The worse the life is today, the more powerful is the heroic-ascetic myth of the great past, the symbolic achievements of the superpower.

Who am I, citizen of the $21^{\text {st }}$ century Ukraine: Slav, Orthodox, Catholic, European or Ukrainian, representative of a prosperous country, poor relative of prosperous Europe, younger brother or elder son...? Unfortunately, in the present circumstances, when the main characteristics of the "social space" are systematically changing, the individual somehow loses the cultural and value bases for self-determination, without having to reconsider new realities and their place in them individually. The dramatic increase in the speed of destruction of old values, the narrowing of the timeframe of this process does not allow the symbols and signs of the new culture to adapt to the traditional sign system of values. In Ukrainian realities, it is not only about the mass influence of the Western culture, but also the gradual overcoming of the negative aspects of the Soviet culture in the need to revive its own national cultural traditions. Thus, the "cultural space" for the self-determination of a person of transitional age contains several value systems that are often contradicted at both individual and social levels.

Such factors as cultural and historical traditions, religious values and ethno-national characteristics of a particular people play an important role in the civilizational context of self-determination of a personality. Global processes of "interaction" and "clash of civilizations" begin to exert a powerful influence on the character of self-assertion of personality in the $\mathrm{XX}-\mathrm{XXI}$ centuries. A significant problem is the change in the concept of globalization regarding non-Western civilizations: the replacement of the "power model" with the "model of interest" when the West recognizes the value of the East and discontinues the practice of imposing (or "blurring") the traditional foundations of non-Western cultures. The counter-desire of the East to cooperate with the West is of utmost importance.

In the process of self-determination, the individual must rely not only on the national civilizational but also on universal human planetary values, which should not be identified with the "values of globalization", which have a 
predominantly Western connotation. Planetary consciousness, in our opinion, encompasses all positives created by various civilizations. But the selfdetermination of the individual is first and foremost his own choice of a system of value orientations that are realized in cultural, social, existential and situational spaces. The important role is played by the system of upbringing and education, which operate in a certain country since these factors have a decisive influence on the nature and content of self-determination of the personality.

Undoubtedly, transformational or modernization changes in the Ukrainian economy, politics, and spiritual life have comprehensively influenced the selfdetermination and self-identification of the individual. But, at the same time, they split society, dividing it into right and left, national patriots and separatists, rich and poor. Therefore, the self-determination and selfidentification of the "Ukrainian man" went a contradictory way accompanied by social conflicts, ideological confrontation, and separatism in some regions. Is it possible to find a universal means of identification in such a situation, or to admit, Yaroslav Grytsak asks, that "it is possible to be Ukrainian differently, as in the long run there are various ways to be human" ${ }^{\circ}$ ?

We share Ihor Solomadyn's opinion, who emphasizes that in the context of multiculturalism "we need to develop the notion of act-responsible identification. It is the definition of oneself as a person of culture who is aware of own unique and unparalleled place in life feeling personal responsibility for what was, and will be, with his people and country in the context of world historic and modern being. And if such an internal orientation is formed, then language problems will not become an obstacle because they are not the essence, but in the inner state that produces emotional and volitional impulses for overcoming inherited obstacles, in the cultural mood that we consider to be our personal achievement"7.

We believe that the problem of disintegration, manifested in the ethnic, denominational and civilizational divisions of the state, lies in the gap and disproportion between the deep spiritual content of culture and its representative forms. We agree with O. Tkachenko, who emphasizes that "the mentality of any society is directly linked to tradition and cannot be radically changed in the short term. Thanks to tradition, self-preservation, reproduction and regeneration of ethnic culture as a system takes place in the society and, acting as a preventative mechanism in the structure of society on the one

\footnotetext{
${ }^{6}$ Грицак Я. І ми в Європі? //Критика, 2003/4 (66). - С. 8.

7 Соломадин I. Гуманітарне мислення у пошуках ідентичності на "болючих швах" полікультурності // Україна - проблема ідентичності: людина, економіка, суспільство Конференція українських випускників програм наукового стажування у США, Львів, 18-21 вересня 2003 p. - URL: https://www.wilsoncenter.org/sites/default/files/Identity.pdf
} 
hand, it is one of the means of changing it on the other. Therefore, any reforms that deny or challenge the traditional outlook of the people cannot be successful and can lead to a worldview and identification crisis." ${ }^{8}$ And without such a tradition, all scientific and political discussions have neither meaning, nor significant social impacts.

\section{The problem of national and ethnic identity}

People identify themselves by means of the following concepts: "origin", "religion", "language", "history", "values", "customs" and "social institutions" etc. They identify themselves with cultural groups: tribes, ethnic groups, religious communities, nations and civilizations, at the broadest level of identification. In analyzing the essence of national and ethnic identity, there are several basic approaches:

- constructivist (B. Anderson, E. Hobsbawm, V. Tishkov), explaining national and ethnic identity as constructed reality, not as objective reality;

- primordial (C. Geertz, S. Greenberg, E. Smith, W. Connor), which considers ethnicity as a community with objective characteristics of belonging: territory, language, race type, religion, mental composition, world outlook, etc.);

- instrumentalist (S. Olzak, J. Nagel, F. Barth), assume that ethnicity is determined ad hoc;

- theory of ethnos (Yu. Bromley, M. Mnatsakyan).

The evolution of the concept of identity in its philosophical hypostasis is discussed in detail by V. Abushenko ${ }^{9}$ in his article on the subject in the encyclopedia of postmodernism. The researcher distinguishes three disciplinary distinct and autonomous, albeit related, understandings of this concept. The proposed strategies for the constitution of multicultural identity correlate with the philosophical ideas of the fundamental incompleteness of man, the openness of identity to the future, its temporal dimension.

By questioning the significance of ethnic and national constituents in the overall identity structure, scholars draw a distinction between these components, which does not prevent them from reaching typologically similar conclusions about the impossibility of a "monologic", unitary understanding of identity in modern circumstances.

When considering and analyzing such a phenomenon as national identity, two main aspects of cultural identity and political identity should be analyzed.

\footnotetext{
${ }^{8}$ Ткаченко О.А. Духовність традиції: соціально-філософський аналіз : автореф. дис. ... канд. філос. наук : 09.00.03 / О.А. Ткаченко ; Нац. пед. ун-т ім. М.П. Драгоманова. - К., 2010. - 19 c.

9 Абушенко В.Л. Идентичность. В: Постмодернизм. Энциклопедия. Минск: Интерпресс-сервис: 2001. - С. 297-302.
} 
Considering the same ethnic identity, it is necessary to carry out a detailed analysis of the cultural basis on which this identity is based. Therefore, when talking about ethnic identity, the main focus is on conscious belonging to the cultural community. That is, ethnic identity is the state of the process of identifying a person (at a certain point in time), who, in addition to his own individual uniqueness, is aware of his or her belonging to a particular cultural community and is associated with a sense of solidarity through shared values and views.

National identity is defined as the process of identification, of likening oneself to a particular nation. The personality shows a subjective sense of belonging to the national community, acceptance of its group norms and values. Namely: awareness of one's own consent and involvement in a number of values concerning one's mother tongue, religion, ethics, cultural heritage, which are enshrined in the unified system of political and public organizations of a state. This is a certain self-identification of individuals in the national context.

Scholars identify the five most important formation sources of national identity. First, it is human beliefs: a nation exists as long as its members recognize each other as compatriots, recognize that their shared characteristics are similar, and jointly strive to continue their coexistence; second - shared historical past, shared responsibilities and ideas about a shared future; third joint action (decision, achievement of results), i.e. active identity; fourth permanent residence in one country, homeland, state; fifth - common characteristics that combine the notion of "national character", a common culture, common political principles (democracy or the rule of law).

One of the recognized Western authorities in the issue of national identity, E. Smith ${ }^{10}$ characterizes it as an abstract, multidimensional construction, linked to many different spheres of life and prone to numerous transformations and combinations. Its main features are historical territory, common myths and historical memory, a common culture, common legal rights and obligations for all members, a common economy. The notion of national identity implies, first of all, the identity, historical identity, and the presence of a popular national idea. National identity can be bizarrely combined with other varieties of identities - class, religious, ethnic, and its ideology - to transform like a chameleon into other ideological varieties: liberalism, fascism and communism.

If ethnic identity is based on a certain system of objective identities racial, cultural, psychological (anthropological type, language, religious

\footnotetext{
${ }^{10}$ Сміт Е. Національна ідентичність // Ентоні Сміт; [Пер. з англ. Петро Таращук]. - К. : Основи, 1994. - 224 с.
} 
dogmas, traditional rite), then the constitutive basis of national identity are the signs, much less "tangible" - consciousness, political will, citizenship. One can be an ethnic Ukrainian but cannot be Ukrainian spiritually. The sources of "elusiveness" of national identity are obviously in this plane.

One of the main components and an important factor in the existence and preservation of ethnic identity is its unique feature. It plays an extremely important role as the basis of the social consciousness of a particular individual or community. The German philosopher M. Heidegger said that language is the home of being. It is the house where being lives. It lives by the laws of this house. Each nation is seemingly surrounded by a circle of its own language and can leave this circle only by moving to another (Wilhelm von Humboldt). Considering the language in the broadest sense, T. Bilenko emphasizes that "an important problem in the context of globalism is the preservation of its uniqueness and continuity in the language of every nation because it is a unique and unparalleled treasure that enables the people to preserve their own identity in the centuries and inherit it for generations to come."11 Thus, language is closely connected with the thinking and psychology of man, with the public and the mass consciousness, with the life of ethnic communities and modern nations, with the history of peoples and their customs. In ontological and ethno-psychological terms, language emerges as one of the most important phenomena of national culture. In his work "Ukrainian Culture" I. Ohienko stated: "Language is our national feature, our culture is in the language, the degree of our consciousness. Language is a form of our life, a cultural and national life; it is a form of national organization. Language is the soul of every nationality, its sanctity, its most precious treasure ... And as long as the language lives, so will the nation, as a nationality"12.

Cultural identity, traditions, customs, food, diminution, clothing, and other objective factors are essential for ethnic identity. It is also difficult to overestimate the value of subjective factors, such as ethnic awareness, ethnic feelings, ethnic consciousness, etc. Ethnicity is to a certain extent determined by the fact what in the end a person feels and thinks about himself. After all,

11 Біленко Т.І. Мова, хронотоп і глобалізаційний процес // Людинознавчі студії: Збірник наукових праць Дрогобицького державного педагогічного університету ім. І. Франка. / T.I. Біленко. - Дрогобич: Науково-видавничий центр ДДПУ ім. І. Франка, 2008. - Вип. 18. Філософія. - С. 85.

${ }^{12}$ Огієнко I. I. Українська культура. Коротка історія культурного життя українського народу : курс, читаний в Українськім народнім університеті : $з$ малюнками і портретами українських культурних діячів / Іван Іванович Огієнко. - Репринт. відтвор. вид. 1918 р . Київ : Абрис, 1991 .- С. 239-240. 
self-awareness, self-determination of the person is one of the main answers to a person's need to belong to a community in order to survive.

National identity is first and foremost a representation of oneself as a national community, a nation. When people consider themselves to be part of such a community and are aware of the distinctive features of that community, one can claim the existence of national consciousness (identity). This is not just about separating "us" from "them." National identity is a much more complex phenomenon.

In situations of acute social instability, it is the ethnic communities that play a crucial role in the self-preservation of the individual or group with which he identifies himself. This largely explains the spread of separatism, fundamentalism, xenophobia, etc., which are to be understood as symptoms of social disorientation, the rupture of those bonds from which the familiar fabric of human community was woven. The power of xenophobia is in fear of the unknown, the darkness that can cover people as soon as the boundaries of the land disappear, meaning the objective, permanent, positive boundaries of being together. And this collective belonging, preferably to groups or associations with certain membership symbols and insignia, is now more important than ever before for societies whose all powers seemingly have united in order to destroy relations, that bind human beings into different communities. It is then when society declines that a nation or an ethnic group remains the last refuge.

In the past, individuality of a person was determined by its origin and belonging to a certain social layer. In modern society, identity has ceased to be a reality. Man as integrity now finds himself in his activity and in this respect constantly controls himself. Individuals can choose and construct their own sameness with a particular community, a way of life that determines the multifaceted nature of identities.

National identity is not a product of the development of ethnic communities. It has its own basis of identification in the form of political communities of citizens. None of the emerging nations possessed a unity of cultural traits (language, traditions and customs) at the time of their origin. Nations were and are multicultural and multi-ethnic formations.

Ethnic and national identity has varying degrees of resilience. The choice of national identity is driven by the political and economic preferences of individuals, making it situational.

Feeling oneself as "postmodernity" necessitates the question of choosing from the many spiritual and cultural alternatives that history offers. Many of the problems that postmodern culture "demonstrates" can find solutions within the Christian tradition that can help to find ways out of the chaos we find ourselves in, to restore faith and the lost meaning of the lives of several 
generations. Traditional-cultural norms of Christianity are absolute and immortal human values that do not change in time and space, but on the contrary are enriched by the values of each new generation.

It is no coincidence that many contemporary studies emphasize such an important factor in national self-identification as ethno-confessional. This special national creative energy is endowed by the church on the condition of spiritual and cultural social interpenetration and mutual enhancement of social progress, as a full trust between the spiritual and social environments, which results in more pronounced ethnic coordinates. Ukrainian ethnic history is filled with the facts of constructive interaction between the Church and the socium in ethnic self-preservation and self-protection and at the same time we keep in mind the destructive mission of the colonial church of the ethnic matrix. In particular, the Ukrainian scholar in this field S. Zidioruk emphasizes the necessity of adopting the definition of a "national church" that would meet the requirements of the times. He writes: "The National Church is the Church of any denomination, which functions in a certain historical period, based on its tradition, in the designated territory; contributes to the acquisition of ethno-confessional specificity, the advancement of ethnoculture, self-consciousness and the state mentality of a given nation and has a significant level of distribution among the population of the country or in the environment of a particular nation" $"$.

Referring to a large number of examples from the historical landscapes of Ireland, Switzerland, Egypt, the myths of Arthur's Britain, Holy Russia and Byzantium, the memoirs of the "golden age" and up-to-date honors of the "heroically dead" and victims of the war, the British social scientist E. Smith justifies indispensability of sacred experience for formation of national identity, in particular in connection with the idea of distinctness ${ }^{14}$. He makes an important for this study conclusion: since the covenant between God and Abraham in the Old Testament, the idea that a particular people were chosen by God plays a central role in shaping national identity, whilst sacred beliefs remain central to national identity, even in an increasingly secularized and globalized world.

One of the important criteria for the ethnic basis of national culture is its organic nature (M. Trubetskoy). Culture develops organically if there is evidence that it has a deep philosophical tradition.

Can we claim that Ukraine has an understanding of the importance of spiritual life, the priority of spiritual values over purely rationalistic values

13 Здіорук C.I. Етноконфесійна ситуація в Україні та міжцерковні конфлікти / С.I. Здіорук. - Препр. / НІСД. - К.: НІСД, 1993. - С. 12.

${ }_{14}$ Сміт Е. Нації та націоналізм у глобальну епоху/ Ентоні Сміт; Пер. 3 англ. М. Климчука і Т. Цимбала. - К. : Ніка-Центр, 2006. - С. 176. 
that have established themselves in European culture under the influence of modern times and the Enlightenment? Without a doubt, yes. Ukrainian philosophy is the bearer of Christian values and humanistic culture.

In their philosophical views, Ukrainian thinkers sought to reproduce spiritual traditions, cordocentrism, existentiality, anthropocentrism of the Ukrainian outlook mentality. This was manifested in the emphasis on the uniqueness of the spiritual essence of man, recognition of the individual as the highest value of being, the consideration of the "heart" as the basis of the spiritual life of man, application of ethics principles in philosophical thought, the revival of the patristic tradition.

Based on the separation of two interrelated levels of national mentality (spiritual, religious and cultural-historical), we emphasize that the inner world and the inner mentality of Ukrainians have always been shaped by the cultural and historical traditions of Christianity. With the development of history, its components partially change but these changes are not sufficient to change the deep mental foundations, which are a form of manifestation of the eternal, involving each new generation in the eternal. "Kyiv statehood reminds us that by the flesh we are the children of beautiful and noble people and by the spiritual essence we are "children of light" in the words of the apostle"15. An important guarantor of the identity of Ukraine is a state with a Christian mentality and way of life as a continuity of cultural and traditional heritage, which must be restored and adapted to modern conditions, without losing its true meaning.

In the process of self-determination, the individual must rely not only on national civilizational values, but also on universal, planetary ones, which should not be identified with the "values of globalization", which have a predominantly Western connotation. Planetary consciousness, in our opinion, encompasses all positives created by various civilizations. Self-determination of the personality is first and foremost its own choice of a system of value orientations that are realized in cultural, social, existential and situational spaces. The important role is played by the system of upbringing and education operating in a particular state, since these factors have a decisive influence on the nature and content of self-determination of the individual.

\section{CONCLUSIONS}

Research of mentality is one of the most interesting directions for understanding both human and community relationships with the cultural and natural environment, to see how meaningful these connections are and what

\footnotetext{
15 Яровий О. Ріка води живої. Хрещення Русі як тисячолітня “свята реальність” і дороговказ для XXI віку. / Олександр Яровий // Інтернет сайт УПЦ Україна православна. URL:: http://www.pravoslavye.org.ua/index.php?action=fullinfo\&r_type=\&id=3549.
} 
happens when these relationships are lost and what mechanisms are in place to install the new ones. The very concept of mentality, according to the researchers, shows that collective emotions and typical reactions of ethnos affect social relations no less than rational motives.

Today, the roots of the problems in Ukrainian society must be sought not in the economy, politics or other spheres of human life, but in the spiritual sphere. It is the crisis in the social and religious sphere that is the beginning that nourishes and binds economic and political crises into one knot.

As an effective methodological tool, mentality is a kind of community memory about its past, ancestral memory, people's worldview and behavior; it allows us to determine the state of the community and its culture, to study their urgent problems.

As we embark on the path of national revival, we must realize that, since ancient times, Ukraine was confronted with the need to search for its own identity in the face of a constant change of actions and scenery on the stage where its historical drama took place. As a consequence, there is centuries-old instability of cultural equilibrium and constant changes of mentality under the influence of the meanings of life, values, realities of the surrounding reality.

The formation of the mentality of the people is a long process that spans the life of more than one generation. Changes to its foundations are much slower than changes in the economic or political spheres. Therefore, the national mentality always retains the potential to influence changes in the society. In certain circumstances, it is capable of acting either as an inertial force that impedes changes in society or acts as a basis for accelerating and validating these processes.

In situations of acute social instability, it is the ethnic communities that play a crucial role in the self-preservation of the individual or group with which he identifies himself. An important guarantor of the identity of Ukraine is a state with a Christian mentality and way of life as a continuity of cultural and traditional heritage, which must be restored and adapted to modern conditions without losing its true meaning. Without such a living Tradition, all scientific and political discussions have neither sense nor significant social impacts.

\section{SUMMARY}

The article analyzes interrelation of mentality, national identity and processes of integration and disintegration of the modern Ukrainian society. It is substantiated that the problem of disintegration, which manifests itself in the ethnic, confessional and civilizational divisions of the state lies in the gap and disproportion between the deep spiritual content of culture and its representative forms. The problems of national, ethnic identity are directly related to the spiritual-religious and cultural-historical levels of the Ukrainian 
mentality. It is emphasized that in situations of acute social instability, it is the ethnic communities that play a crucial role in the self-preservation of the individual or a group with which he identifies himself.

\section{REFERENCES}

1. Абушенко В.Л. Идентичность. В: Постмодернизм. Энциклопедия. Минск: Интерпресс-сервис: 2001. - С. 297-302.

2. Біленко T.I. Мова, хронотоп i глобалізаційний процес // Людинознавчі студії: Збірник наукових праць Дрогобицького державного педагогічного університету ім. І. Франка. / Т.І. Біленко. Дрогобич: Науково-видавничий центр ДДПУ ім. І. Франка, 2008. Вип. 18. Філософія. - С. 78-89.

3. Грицак Я. І ми в Європі? // Критика, 2003/4 (66). - С. 5-8.

4. Гуревич А. Ментальность / М. Вовель, А. Гуревич, М. Рожанский // 50/50. Опыт словаря нового мышления. [Под общ. ред. Ю. Афанасьева и М. Ферро]. - М. : Прогресс - Payot. 1998. - С. 454-463.

5. Додонов Р.А. Этническая ментальность: опыт социальнофилософского исследования: Монографія / Р.А. Додонов. - Запорожье: “Тандем-У”, 1998. - 205 с.

6. Здіорук C.I. Етноконфесійна ситуація в Україні та міжцерковні конфлікти / С.І. Здіорук. - Препр. / НІСД. - К.: НІСД, 1993. - 59 с.

7. Кузьменко H.I. Постмодерний університет і цивілізаційна ідентичність: ціннісний аспект / Н.I. Кузьменко, О.О. Демченко // Вісник НТУУ “КПІ”. Філософія. Психологія Педагогіка. - 2014. - Вип. 3. C. $10-19$.

8. Огієнко I.I. Українська культура. Коротка історія культурного життя українського народу : курс, читаний в Українськім народнім університеті : $з$ малюнками і портретами українських культурних діячів / Іван Іванович Огієнко. - Репринт. відтвор. вид. 1918 р. - Київ : Абрис, 1991. $-272 \mathrm{c}$.

9. Пелагеша Н. Україна у смислових війнах постмодерну: трансформація української національної ідентичності в умовах глобалізації: монографія / Н. Пелагеша. - К. : НІСД, 2008. - 287 с.

10. Сміт Е. Національна ідентичність // Ентоні Сміт; [Пер. 3 англ. Петро Таращук]. - К. : Основи, 1994. - 224 с.

11. Сміт Е. Нації та націоналізм у глобальну епоху / Ентоні Сміт; Пер. 3 англ. М. Климчука і Т. Цимбала. - К. : Ніка-Центр, 2006. - 320 с.

12. Соломадин I. Гуманітарне мислення у пошуках ідентичності на “болючих швах" полікультурності // Україна - проблема ідентичності: людина, економіка, суспільство Конференція українських випускників програм наукового стажування у США, Львів, 18-21 вересня 2003 р. URL: https://www.wilsoncenter.org/sites/default/files/Identity.pdf 
13. Ткаченко О.А. Духовність традиції: соціально-філософський аналіз : автореф. дис. ... канд. філос. наук : 09.00 .03 / О.А. Ткаченко ; Нац. пед. ун-т ім. М.П. Драгоманова. - К., 2010. - 19 с.

14. Яковенко Н. Паралельний світ. Дослідження з історії уявлень та ідей в Україні XVI - XVII ст. / Н. Яковенко. - Київ : Критика, 2002. $416 \mathrm{c}$.

15. Яровий О. Ріка води живої. Хрещення Русі як тисячолітня “свята реальність” і дороговказ для XXI віку. / Олександр Яровий // Інтернет сайт УПЦ Україна православна. URL: http://www.pravoslavye.org.ua/ index.php?action=fullinfo\&r_type $=\& i d=3549$

\section{Information about the author:} Skotna N. V.,

Doctor of Philosophical Sciences, Professor, Rector, Drohobych Ivan Franko State Pedagogical University 24, Ivan Franko str., Drohobych, 82100, Ukraine 